\title{
PENGARUH PROFITABILITAS, STRUKTUR AKTIVA, DAN UKURAN PERUSAHAAN TERHADAP STRUKTUR MODAL
}

\author{
I Kadek Rico Andika ${ }^{1}$ \\ Ida Bagus Panji Sedana ${ }^{2}$
}

${ }^{1}$ Fakultas Ekonomi dan Bisnis Universitas Udayana (Unud), Bali, Indonesia email: ricoandika@gmail.com

\begin{abstract}
ABSTRAK
Tujuan dari penelitian ini adalah untuk menganalisis signifikansi pengaruh profitabilitas, struktur aktiva, dan ukuran perusahaan terhadap struktur modal. Penelitian ini dilakukan pada Perusahaan Makanan dan Minuman di Bursa Efek Indonesia (BEI) periode 20142017. Jumlah sampel penelitian ini adalah 14 perusahaan, dengan metode purposive sampling. Pengumpulan data dilakukan dengan metode observasi non partisipan yaitu melalui data laporan keuangan yang dipublikasikan pada website www.idx.co.id. Berdasarkan hasil analisis ditemukan bahwa profitabilitas tidak berpengaruh terhadap struktur modal. Struktur aktiva dan ukuran perusahaan berpengaruh positif dan signifikan terhadap struktur modal. Hal ini menunjukkan bahwa manajer perusahaan harus mampu mempertimbangkan keputusan pendanaan yang akan diambil, baik menggunakan modal sendiri maupun hutang.

Kata kunci: struktur modal, profitabilitas, struktur aktiva, ukuran perusahaan
\end{abstract}

\section{ABSTRACT}

The purpose of this study is to analyze the significance of the effect of profitability, asset structure, and firm size on capital structure. This research was conducted on Food and Beverage Companies on the Indonesia Stock Exchange (IDX) for the 2014-2017 period. The number of samples of this study were 14 companies, with a purposive sampling method. Data collection is done by non-participant observation method, namely through financial report data published on the website www.idx.co.id. Based on the results of the analysis it was found that profitability did not affect the capital structure. The asset structure and size of the company have a positive and significant effect on the capital structure. This shows that company managers must be able to consider the funding decisions that will be taken, both using their own capital and debt.

Keywords: capital structure, profitability, asset structure, firm size 


\section{PENDAHULUAN}

Persaingan bisnis saat ini membuat banyak perusahaan harus berusaha untuk mencapai tujuan utama perusahaannya. Memaksimalkan nilai perusahan merupakan salah satu tujuan utama dari setiap perusahaan. Memaksimalkan nilai perusahaan dengan pemenuhan dana perusahaan yang berasal dari sumber internal maupun eksternal perusahaan. Penentuan jumlah proporsi antara hutang jangka panjang dengan modal dalam penggunaannya sebagai sumber pendanaan suatu perusahaan memiliki kaitan yang erat dengan struktur modal.

Struktur modal merupakan komparasi antara jumlah hutang jangka panjang dengan modal sendiri lainnya. Struktur modal memiliki peran yang penting karena baik buruknya struktur modal akan berdampak langsung terhadap posisi keuangan perusahaan tersebut. Efek langsung yang disebabkan oleh struktur modal dapat mempengaruhi nilai suatu perusahaan. Struktur modal perusahaan merupakan salah satu faktor fundamental suatu perusahaan yang mencakup keputusan finansial terkait dengan utang jangka panjang maupun utang jangka pendek sebuah perusahaan.

Perusahaan yang akan melakukan ekspansi pastinya membutuhkan modal. Maka dari itu, perusahaan harus menetapkan seberapa besar modal yang dibutuhkan untuk membiayai usahanya. Untuk memenuhi kebutuhan modal, perusahaan dapat memperolehnya dari dana internal dan dana eksternal (Zuliyani \& Asyik, 2014).

Sumber dana internal yaitu dana yang bersumber dari perusahaan sendiri, misalnya laba perusahaan, cadangan atau laba yang ditahan. Sedangkan sumber dana eksternal yaitu dana yang diambil berasal dari pemegang saham maupun pembelanjaan asing misalnya dana yang berasal dari bank.

Manajer keuangan dituntut untuk dapat mengoptimalkan struktur modal perusahaan manajer keuangan dituntut untuk mendapatkan keuntungan yang maksimal. Mengambil keputusan dalam struktur modal, faktor-faktor yang dapat mempengaruhi struktur modal harus di pertimbangkan oleh manajer keuangan. Beberapa faktor-faktor yang mempengaruhi struktur modal diantaranya struktur aktiva, tingkat pertumbuhan penjualan dan profitabilitas.

Perusahaan makanan dan minuman merupakan salah satu kategori sektor industri di Bursa Efek Indonesia (BEI) yang mempunyai peluang untuk tumbuh dan berkembang. Industri makanan dan minuman diprediksi akan membaik kondisinya. Perusahaan makanan dan minuman merupakan salah satu sektor yang diminati oleh para investor, alasannya adalah sektor ini merupakan salah satu sektor yang dapat bertahan di tengah kondisi perekonomian Indonesia, karena pendirian perusahaan makanan dan minuman yang semakin banyak diharapkan dapat memberikan prospek yang menguntungkan dalam memenuhi kebutuhan masyarakat.

Selain itu prospek yang dimiliki oleh perusahaan sektor ini sangat baik karena pada dasarnya setiap masyarakat membutuhkan makanan dan minuman dalam hidup. Selain itu tingkat konsumsi juga dipengaruhi oleh jumlah penduduknya, sehingga konsumsi masyarakat akan bertambah sejalan dengan bertambahnya jumlah penduduk Indonesia tiap tahunnya. Ini merupakan hal yang 
baik karena melihat fenomena jumlah penduduk Indonesia yang terus bertambah pada tiap tahunnya.

Dipilihnya sektor makanan dan minuman karena perusahaan makanan dan minuman memiliki pertumbuhan yang semakin pesat di berbagai daerah indonesia. Pertumbuhan jumlah penduduk di Indonesia yang terus meningkat, mengakibatkan peningkatan pula akan kebutuhan makanan dan minuman. Sektor makanan dan minuman inilah yang memegang peran penting dalam memenuhi kebutuhan konsumen karena bergerak dalam bidang konsumsi. Gemarnya masyarakat dalam berbelanja makanan, dapat membantu mempertahankan sektor dengan baik. Hal tersebut membuat para investor tertarik untuk berinvestasi pada sektor makanan dan minuman karena dilihat dari pertumbuhan yang cukup baik. Berikut merupakan data struktur modal yang diukur dengan Debt to Equity Ratio (DER) pada perusahaan makanan dan minuman tahun $2014-2017$.

Tabel 1.

Struktur Modal Perusahaan Makanan dan Minuman di Bursa Efek Indonesia Tahun 2014-2017 (Dalam Persentase)

\begin{tabular}{|c|c|c|c|c|c|}
\hline NO & Nama Perusahaan & 2014 & 2015 & 2016 & 2017 \\
\hline 1 & PT Tiga Pilar Sejahtera Food Tbk. & $105,6 \%$ & $128,4 \%$ & $117 \%$ & $156,2 \%$ \\
\hline 2 & PT Banyan Tirta Tbk. & $132,9 \%$ & $132,8 \%$ & $142,3 \%$ & $164,6 \%$ \\
\hline 3 & PT Wilmar Cahaya Indonesia Tbk. & $138,9 \%$ & $132,2 \%$ & $60,6 \%$ & $54,2 \%$ \\
\hline 4 & PT Delta Djakarta Tbk. & $31,2 \%$ & $22,2 \%$ & $18,3 \%$ & $17,1 \%$ \\
\hline 5 & PT Indofood CBP Sukses Makmur Tbk & $71,6 \%$ & $62,1 \%$ & $56,2 \%$ & $55,6 \%$ \\
\hline 6 & PT Indofood Sukses Makmur Tbk & $113,7 \%$ & $113,0 \%$ & $87,0 \%$ & $88,1 \%$ \\
\hline 7 & PT Multi Bintang Indonesia Tbk & $302,9 \%$ & $174,1 \%$ & $177,2 \%$ & $135,7 \%$ \\
\hline 8 & PT Mayora Indah Tbk & $152,6 \%$ & $118,4 \%$ & $106,3 \%$ & $102,8 \%$ \\
\hline 9 & PT Prashida Aneka Niaga Tbk & $67,5 \%$ & $91,3 \%$ & $133,3 \%$ & $130,7 \%$ \\
\hline 10 & PT Nippon Indosari Corporindo Tbk & $124,7 \%$ & $127,7 \%$ & $102,4 \%$ & $61,7 \%$ \\
\hline 11 & PT Sekar Bumi Tbk & $112,3 \%$ & $122,2 \%$ & $171,9 \%$ & $58,6 \%$ \\
\hline 12 & PT Sekar Laut Tbk & $145,4 \%$ & $148,0 \%$ & $91,9 \%$ & $106,9 \%$ \\
\hline 13 & PT Siantar Top Tbk & $108,5 \%$ & $90,3 \%$ & $99,9 \%$ & $69,2 \%$ \\
\hline 14 & $\begin{array}{l}\text { PT Ultrajaya Milk Industry and Trading } \\
\text { Company Tbk }\end{array}$ & $28,4 \%$ & $26,5 \%$ & $21,5 \%$ & $23,2 \%$ \\
\hline 15 & PT Campina Ice Cream Industry Tbk & - & - & - & $44,5 \%$ \\
\hline 16 & PT Sariguna Primatirta Tbk & - & - & - & $121,8 \%$ \\
\hline 17 & PT Buyung Poetra Sembada Tbk & - & - & - & $21,2 \%$ \\
\hline 18 & PT Prima Cakrawala Abadi Tbk & - & - & - & $46,9 \%$ \\
\hline & Rata-rata & $116,9 \%$ & $106,4 \%$ & $99,0 \%$ & $81,1 \%$ \\
\hline
\end{tabular}

Sumber: Data diolah, 2018

Berdasarkan Tabel 1. menunjukan bahwa tingkat Debt to Equity Ratio (DER) setiap perusahaan makanan dan minuman dari tahun 2014 - 2017 sangat bervariasi. Data di atas juga menunjukan rata-rata DER perusahaan makanan dan minuman mengalami penurunan dari tahun 2014 - 2017 sebesar 116,9\% menjadi $81,1 \%$ pada tahun 2017, namun tidak semua penurunan terjadi di setiap perusahaan. Sebagian besar perusahaan memiliki nilai DER yang berfluktuasi setiap tahunnya. Perusahaan yang memiliki nilai DER berfluktuasi sebanyak 10 perusahaan, 4 perusahaan memiliki nilai DER yang menurun setiap tahunnya dan 4 perusahaan baru menerbitkan sahamnya pada tahun 2017. Berfluktuasinya nilai 
DER ini juga yang membuat peneliti tertarik menjadikan perusahaan makanan dan minuman sebagai objek penelitian.

Struktur modal didefinisikan sebagai perimbangan atau perbandingan antara jumlah hutang jangka panjang dengan modal sendiri. Lisa (2016) menyatakan struktur modal perusahaan menggambarkan keseimbangan antara ekuitas dan utang jangka panjang. Dengan demikian, perusahaan harus selalu memperhatikan struktur modal yang tepat dalam urutan yang baik. Modal dapat diperoleh dari sumber internal dan eksternal dalam hal ekuitas dan utang, sementara struktur modal adalah arah bagi perusahaan untuk meningkatkan keuangan melalui kombinasi ekuitas dan utang (Huang dan Song, 2006).

Yat-Hung dan Cheng (2010) menyatakan bahwa struktur modal mengacu pada kombinasi ekuitas dan utang yang diterbitkan untuk tujuan membiayai perusahaan. Meminimalisir ketergantungan dari pihak luar, perusahaan tentu akan lebih memilih modal dari dalam. Akan tetapi, ada kalanya modal dari dalam tidak mencukupi untuk memenuhi kebutuhan perusahaan ataupun untuk mengembangkan perusahaan. Oleh karena itu perusahaan juga membutuhkan dana dari pihak luar dalam situasi tertentu.

Struktur modal dipengaruhi oleh beberapa variabel. Berdasarkan pada beberapa penelitian sebelumnya, variabel pertumbuhan penjualan, profitabilitas, struktur aktiva dan ukuran perusahaan teridentifikasi bepengaruh terhadap struktur modal. Pada penelitian Songul (2015) mengungkapkan variabel bebas dari struktur modal adalah peluang pertumbuhan, ukuran, profitabilitas, tangibility, dan NDTS. Penelitian Asmawi and Faridah (2013) menyatakan variabel independen atau variabel penjelas struktur modal yang telah diidentifikasi terdiri dari usia, ukuran, tangibility, likuiditas, profitabilitas, pertumbuhan, investasi dan perpajakan.

Terdapat beberapa teori mengenai struktur modal, menurut Brigham dan Houston (2011:179-185) diantaranya Modigliani-Miller (MM) Theory, Trade- Off Theory atau Teori pertukaran, dan Signalling Theory (Teori Sinyal). Sedangkan menurut Husnan (2012:278) terdapat Pecking Order Theory yang juga merupakan teori yang mendasari struktur modal.

Profitabilitas yang merupakan kemampuan perusahaan dalam mencapai keuntungan serta menjadi ukuran tingkat efektivitas manajemen perusahaan, yang ditunjukkan oleh laba yang dihasilkan oleh perusahaan dari hasil penjualan dan pendapatan investasi. Profitabilitas merupakan salah satu faktor yang memiliki pengaruh terhadap struktur modal. Menurut Wiagustini (2014, p. 86) profitabilitas, menunjukan kemampuan perusahaan memperoleh laba atau ukuran efektivitas pengelolaan manajemen perusahaan. Suatu perusahaan yang memiliki profitabilitas tinggi maka akan menghasilkan return yang besar sehingga banyak investor yang berminat untuk berinvestasi pada perusahaan tersebut. Dengan analisis profitabilitas, dapat mengidentifikasi penyebab untung atau rugi. Profitabilitas dalam penelitian ini diukur dengan Return on assets (ROA), dikarenakan ROA mencerminkan tingkat pengembalian dari modal yang diinvestasikan oleh perusahaan dalam keseluruhan aktiva. Semakin tinggi nilai ROA maka laba yang dihasilkan akan semakin tinggi sehingga semakin banyak 
kas internal yang dimiliki sebaliknya kebutuhan akan dana eksternal akan berkurang.

Hasil penelitian sebelumnya tentang pengaruh profitabilitas terhadap struktur modal masih memperlihatkan hasil yang tidak konsisten. Penelitian Andika (2016) dan Turki (2014) menjelaskan, bahwa profitabilitas berpengaruh positif sedangkan menurut penelitian Asmawi and Faridah (2013), Widianti (2015), Gamaliel (2015) dan Michael and Stevie (2012) profitabilitas berpengaruh negatif terhadap struktur modal.

Perusahaan yang struktur aktivanya memiliki perbandingan aktiva tetap jangka panjang lebih besar akan menggunakan hutang jangka panjang lebih banyak karena aktiva tetap yang ada dapat digunakan sebagai jaminan hutang. Semakin tinggi struktur aktiva maka semakin tinggi struktur modalnya berarti semakin besar aktiva tetap yang dapat dijadikan agunan utang oleh perusahaan tersebut (Chowdhury \& Chowdhury, 2012). Sebaliknya, semakin rendah struktur aktiva dari suatu perusahaan, semakin rendah kemampuan dari perusahaan tersebut untuk dapat menjamin utang jangka panjangnya (Kesuma, 2009).

Struktur aktiva dapat digunakan untuk menentukan seberapa besar hutang jangka panjang yang dapat diambil dan hal ini akan berpengaruh terhadap penentuan besarnya struktrur modal. Teori struktur modal mengungkap adanya korelasi positif antara tingkat hutang dan struktur aktiva. Perusahaan yang memiliki banyak struktur aktiva memiliki jaminan yang cukup atas pinjaman mereka. Struktur aktiva juga berarti bahwa perusahaan memiliki nilai likuidasi tinggi, sehingga kreditur dapat menerima kembali dana mereka jika terjadi likuidasi perusahaan. Dengan demikian semakin banyak struktur aktiva yang dimiliki perusahaan, maka semakin tinggi motivasi kreditur menyetujui kredit tingkat hutang.

Menurut penelitian yang dilakukan oleh Widianti (2015), Naibaho (2015), dan Gamaliel (2015) menyatakan bahwa struktur aktiva berpengaruh positif terhadap struktur modal sedangkan menurut penelitian Andika (2016), Rofiqoh dan Kurnia (2014) menunjukan bahwa struktur aktiva berpengaruh negatif terhadap struktur modal.

Ukuran perusahaan digambarkan oleh besar kecilnya suatu perusahaan. Ukuran perusahaan akan menjadi acuan kemungkinan perusahaan gagal dalam mengembalikan utangnya. Perusahaan besar akan lebih mudah memperoleh suatu pinjaman jika dibandingkan dengan perusahaan kecil. Semakin besar ukuran perusahaan tersebut, maka semakin mudah mendapatkan modal eksternal dalam jumlah yang besar terutama dalam bentuk hutang. Dengan kata lain, besar kecilnya ukuran suatu perusahaan secara langsung berpengaruh terhadap kebijakan struktur modal perusahaan. Hal tersebut berkaitan dengan tingkat kepercayaan kreditur kepada perusahaan yang dapat mengembalikan hutanghutangnya dengan segera.

Hasil penelitian sebelumnya tentang pengaruh ukuran peusahaan terhadap struktur modal masih memperlihatkan hasil yang tidak konsisten. Penelitian Andika (2016), Gamaliel (2015), Widianti (2015), Salehi dan Nazanin (2012) menjelaskan bahwa ukuran perusahaan berpengaruh positif sedangkan menurut 
penelitian Naibaho (2015) ukuran perusahaan berpengaruh negatif terhadap struktur modal.

Kerangka konseptual merupakan suatu hubungan atau kaitan antara konsep satu terhadap konsep yang lainnya dari masalah yang ingin diteliti. Kerangka berpikir dapat digunakan sebagai pendekatan dalam memecahkan masalah. Penelitian ini menggunakan variabel profitabilitas sebagai (X1), struktur aktiva sebagai (X2) dan variabel ukuran perusahaan sebagai (X3) yang akan diuji sebagai faktor yang dapat mempengaruhi struktur modal (Y). Kerangka konseptual dalam penelitian ini, dapat digambarkan sebagai berikut:

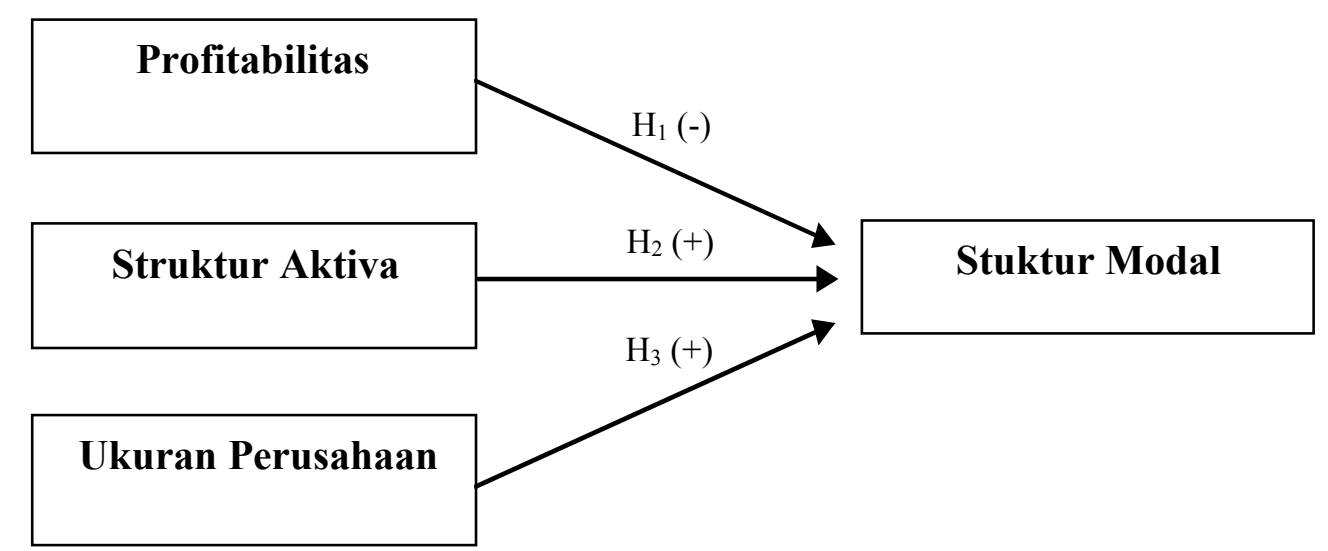

Menurut Fahmi (2013, p. 135) definisi profitabilitas adalah mengukur efektivitas manajemen secara keseluruhan yang ditunjukkan oleh besar kecilnya tingkat keuntungan yang diperoleh dalam hubungannya dengan penjualan maupun investasi. Sementara itu rasio profitabilitas adalah rasio-rasio yang menghubungkan perbandingan laba dengan penjualan serta investasi serta rasio yang menunjukkan hasil akhir dari kebijaksanaan dan keputusan-keputusan (Profit Margin On Sales, Return On Assets, Return On Wealth dsb).

Profitabilitas pada perusahaan menunjukkan kemampuan perusahaan memperoleh laba yang diperoleh dari hasil operasionalnya. Profitabilitas dapat diukur dengan menggunakan ROA, dimana ROA Merupakan alat ukur untuk mengetahui kemampuan perusahaan memperoleh keuntungan dari dana yang diinvestasikan terhadap aset perusahaan. Perusahaan pada umumnya cenderung memilih pembiayaan operasionalnya dengan sumber dana internal sebelum menggunakan sumber dana eksternal. Hal ini dikarenakan sumber dana internal dianggap lebih murah dan memiliki tingkat risiko yang rendah dibandingkan dengan menggunakan sumber dana eksternal.

Menurut pecking order theory, perusahaan dengan tingkat keuntungan yang besar memiliki sumber pendanaan internal yang lebih besar dan memiliki kebutuhan untuk melakukan pembiayaan investasi melalui pendanaan eksternal yang lebih kecil (Adrianto \& Wibowo, 2007). Apabila dalam komposisi struktur modal penggunaan modal sendiri lebih besar daripada penggunaan hutang, maka rasio struktur modal akan semakin kecil. Penelitian yang dilakukan oleh Firnanti (2011), Indrajaya et al. (2011), Kartika (2009), dan Sari (2014) mengungkapkan 
bahwa profitabilitas berpengaruh negatif dan signifikan terhadap struktur modal. Maka, hipotesis yang dapat dirumuskan adalah:

$\mathrm{H}_{1}$ : Profitabilitas berpengaruh negatif terhadap struktur modal perusahaan makanan dan minuman di Bursa Efek Indonesia.

Menurut Brigham dan Houston (2011, p. 188) perusahaan yang asetnya memadai untuk digunakan sebagai jaminan cenderung akan cukup banyak menggunakan utang. Struktur aktiva atau yang biasa disebut tangibility of Asset adalah penentuan seberapa besarnya jumlah alokasi untuk masing-masing komponen aktiva akan mencerminkan kemampuan atau besarnya jaminan dari aktiva yang dimiliki oleh perusahaan atas jaminan yang dilakukan. Semakin besar struktur aktiva yang dimiliki perusahaan, maka semakin besar juga peluang perusahaan menggunakan hutang. Hal ini disebabkan karena aktiva tetap yang dimiliki perusahaan dapat dijadikan jaminan untuk memperoleh hutang.

Menurut Pecking order theory perusahaan yang sebagian besar aktivanya berupa aktiva tetap akan mengutamakan pemenuhan modalnya dari modal sendiri. Sedangkan peusahaan yang sebagian besar aktivanya berupa aktiva lancar akan mengutamakan pemenuhan dananya dengan hutang.

Menurut Adrianto dan Wibowo (2007), aktiva berwujud yang semakin besar akan menunjukkan kemampuan perusahaan dalam memberikan jaminan yang lebih tinggi, sehingga dengan mengasumsikan semua faktor lain konstan, perusahaan akan meningkatkan utang untuk mendapatkan keuntungan dari penggunaan utang.

Beberapa penelitian yang dilakukan oleh Wijaya dan Utama (2014), Indrajaya et al. (2011), Margaretha dan Ramadhan (2010), dan Putri (2012), mengungkapkan bahwa struktur aktiva berpengaruh positif terhadap struktur modal. Berdasarkan hasil teori dan penelitian terdahulu tersebut dapat dirumuskan hipotesis yaitu:

$\mathrm{H}_{2}$ : Struktur aktiva berpengaruh positif terhadap struktur modal perusahaan makanan dan minuman di Bursa Efek Indonesia.

Ukuran Perusahaan (Firm Size) menggambarkan besar kecilnya suatu perusahaan, perusahaan yang lebih besar akan lebih mudah memperoleh pinjamaan dibandingkan perusahaan kecil. Perusahaan yang lebih besar cenderung memiliki tingkat Leverage yang lebih tinggi dibandingkan dengan perusahaan yang lebih kecil, dimana tingkat kebangkrutannya lebih rendah dari pada perusahaan kecil, semakin besar suatu perusahaan, ada kecenderungan untuk menggunakan jumlah pinjaman yang lebih besar dibandingkan dengan perusahaan kecil. Dengan kata lain bahwa semakin besar perusahaan akan lebih berani untuk berutang. Hal tersebut dilakukan untuk memenuhi kebutuhan operasionalnya yang lebih besar dibandingkan dengan perusahaan kecil.

Semakin besar ukuran suatu perusahaan, maka kecenderungan menggunakan modal asing juga semakin besar. Hal ini disebabkan karena perusahaan besar membutuhkan dana yang besar pula untuk menunjang operasionalnya, dan salah satu alternatif pemenuhannya adalah dengan modal asing apabila modal sendiri tidak mencukupi. 
Perusahaan besar umumnya memiliki total asset yang besar pula sehingga dapat menarik investor untuk menanamkan modalnya pada perusahaan tersebut. Kreditur selalu memiliki suatu pertimbangan ketika akan menginvestasikan dananya, pada dasarnya kreditur cenderung lebih tertarik dengan ukuran perusahaan yang besar dibandingkan dengan ukuran perusahaan yang kecil karena ukuran perusahaan kecil dikhawatirkan memiliki risiko yang besar terkait dengan pengembalian investasi yang tidak diharapkan bagi kreditur.

Ukuran perusahaan menggambarkan besar kecilnya suatu perusahaan, perusahaan yang lebih besar akan lebih mudah memperoleh pinjaman dibandingkan perusahaan kecil. Seperti hasil penelitian Widianti (2015) dan Andika (2016) dalam hasil penelitiannya menyatakan bahwa ukuran perusahaan memiliki pengaruh positif terhadap struktur modal. Berdasarkan penelitian tersebut, hipotesis yang dapat di ajukan sebagai berikut :

$\mathrm{H}_{3}$ : Ukuran perusahaan berpengaruh positif terhadap struktur modal perusahaan makanan dan minuman di Bursa Efek Indonesia.

\section{METODE PENELITIAN}

Pendekatan yang digunakan dalam penelitian ini adalah pendekatan kuantitatif metode asosiatif. Penelitian berbentuk asosiatif yaitu penelitian yang bertujuan untuk mengetahui hubungan antara dua variable atau lebih. Penelitian ini juga menggunakan data sekunder yaitu data yang telah dikumpulkan oleh lembaga pengumpul data serta di publikasikan pada masyarakat pengguna. Data tersebut merupakan data time series periode 2014-2017, yang diperoleh melalui Bursa Efek Indonesia (BEI).

Dalam penelitian ini metode yang digunakan dalam pegumpulam data adalah metode dokumentasi, yaitu dengan mengambil data-data tertulis yang berhubungan dengan struktur aktiva, profitabilitas, ukuran perusahaan, serta mengenai struktur modal berupa data tahunan periode 2014-2017.

Ruang lingkup penelitian ini dilakukan pada seluruh perusahaan makanan dan minuman di Bursa Efek Indonesia (BEI). Data dalam penelitian ini diambil melalui laporan keuangan dari tahun 2014-2017 yang dipublikasikan oleh IDX (Indonesian Stock Exchange). Objek pada penelitian ini adalah struktur modal pada perusahaan makanan dan minuman di Bursa Efek Indonesia periode 20142017.

Populasi yang merupakan wilayah generalisasi yang terdiri atas objek dan subjek yang mempunyai kualitas dan karakteristik tertentu yang ditetapkan oleh penelitian untuk dipelajari dan kemudian ditarik kesimpulannya. Adapun populasi yang digunakan dalam penelitian ini adalah seluruh perusahaan makanan dan minuman yang tercatat di Bursa Efek Indonesia (BEI) yaitu sebanyak 18 perusahaan yang diakses pada www.idx.co.id.

Teknik analisis data dalam penelitian dilakukan dengan bantuan program Statistical Package for the Sosial Science (SPSS). Analisis regresi linier berganda dilakukan untuk mengetahui ketergantungan suatu variabel terikat dengan dua atau lebih pada variabel bebas. Dalam penelitian ini yang menjadi variabel independen $(X)$ adalah Profitabilitas $\left(X_{1}\right)$, Struktur Aktiva $\left(X_{2}\right)$, dan Ukuran Perusahaan $\left(\mathrm{X}_{3}\right)$, sedangkan variabel dependen $(\mathrm{Y})$ adalah Struktur Modal. 
Persamaan regresi linier berganda ditunjukkan sebagai berikut:

$$
\begin{aligned}
& \mathbf{Y}=\boldsymbol{\alpha}+\boldsymbol{\beta}_{\mathbf{1}} \mathbf{X}_{\mathbf{1}}+\boldsymbol{\beta}_{\mathbf{2}} \mathbf{X}_{\mathbf{2}}+\boldsymbol{\beta}_{\mathbf{3}} \mathbf{X}_{\mathbf{3}}+\mathbf{e} \ldots \ldots \ldots \ldots . . . . . . \\
& \text { Keterangan : } \\
& Y \quad=\text { Struktur Modal } \\
& \alpha \quad=\text { Konstanta } \\
& \beta_{1,2,3}=\text { Koefisien Regresi Masing-masing Xi } \\
& X_{1}=\text { Profitabilitas } \\
& X_{2}=\text { Struktur Aktiva } \\
& X_{3}=\text { Ukuran Perusahaan } \\
& e \quad=\text { Residual Eror }
\end{aligned}
$$

\section{HASIL DAN PEMBAHASAN}

Sektor Industri Barang Konsumsi merupakan sektor penyumbang utama pertumbuhan ekonomi Indonesia. Sektor industri barang konsumsi merupakan salah satu sektor yang mempunyai peranan penting dalam memicu pertumbuhan ekonomi Negara. Sektor industri barang konsumsi sangat di butuhkan karena semakin meningkatnya kebutuhan hidup masyarakat Indonesia.

Dalam pelaksanaanya Sektor Industri Barang Konsumsi terbagi menjadi lima macam yaitu subsektor makanan dan minuman, subsektor rokok, subsektor farmasi, subsektor kosmetik dan keperluan rumah tangga, subsektor peralatan rumah tangga.

Penyajian statistik deskriptif dilakukan untuk menginformasikan karakteristik variabel-variabel penelitian, seperti nilai terkecil, nilai terbesar, ratarata dan standar deviasi.

Tabel 2.

Statistik Deskriptif Data Uji

\begin{tabular}{lcrrrr}
\hline & N & Minimum & Maximum & Mean & Std. Deviation \\
\hline DER & 56 & 0,21 & 2,03 & 0,9809 & 0,41529 \\
ROA & 56 & $-0,10$ & 0,53 & 0,0895 & 0,10801 \\
TANG & 56 & 0,07 & 0,89 & 0,3657 & 0,18224 \\
Ukuran Perusahaan & 56 & 14,56 & 30,33 & 23,6959 & 5,62322 \\
Valid N (listwise) & 56 & & & &
\end{tabular}

Berdasarkan hasil statistik deskriptif yang ditunjukkan pada Tabel 2. didapat hasil bahwa sampel yang berjumlah 56 dan mempunyai hasil struktur modal perusahaan (DER) memiliki nilai minimum 0,21. Nilai maksimum sebesar 2,03 dan mean sebesar 0,9809 dengan standar deviasi sebesar 0,41529 artinya terjadi penyimpangan nilai struktur modal perusahaan terhadap nilai rata - ratanya sebesar 0,41529 .

Profitabilitas (ROA) memiliki nilai minimum -0,10. Nilai maksimum sebesar 0,53 dan mean sebesar 0,0895 dengan standar deviasi sebesar 0,10801 
artinya terjadi penyimpangan nilai profitabilitas terhadap nilai rata - ratanya sebesar 0,10801 .

Struktur Aktiva (TANG) memiliki nilai minimum 0,07. Nilai maksimum sebesar 0,89 dan mean sebesar 0,3657 dengan standar deviasi sebesar 0,18224 artinya terjadi penyimpangan nilai struktur aktiva terhadap nilai rata - ratanya sebesar 0,18224 .

Ukuran perusahaan memiliki nilai minimum 14,56. Nilai maksimum sebesar 30,33 dan mean sebesar 23,6959 dengan standar deviasi sebesar 5,62322 artinya terjadi penyimpangan nilai Ukuran Perusahaan terhadap nilai rata - ratanya sebesar 5,62322.

Analisis regresi linier berganda dilakukan untuk mengetahui ketergantungan suatu variabel terikat dengan dua atau lebih pada variabel bebas. Dalam penelitian ini yang menjadi variabel independen $(\mathrm{X})$ adalah Profitabilitas $\left(\mathrm{X}_{1}\right)$, Struktur Aktiva $\left(\mathrm{X}_{2}\right)$, dan Ukuran Perusahaan $\left(\mathrm{X}_{3}\right)$. Hasil analisis regresi linier berganda dapat dilihat pada Tabel 3.

Tabel 3.

Hasil Uji Regresi Linier Berganda

\begin{tabular}{|c|c|c|c|c|c|c|}
\hline \multicolumn{2}{|c|}{ Model } & \multicolumn{2}{|c|}{$\begin{array}{c}\text { Unstandardized } \\
\text { Coefficients }\end{array}$} & \multirow{2}{*}{$\begin{array}{l}\text { Standardized } \\
\text { Coefficients } \\
\text { Beta }\end{array}$} & \multirow[t]{2}{*}{$\mathbf{T}$} & \multirow[t]{2}{*}{ Sig. } \\
\hline & & B & $\begin{array}{l}\text { Std. } \\
\text { Error }\end{array}$ & & & \\
\hline \multirow[t]{4}{*}{1} & (Constant) & $-0,590$ & 0,135 & & $-4,358$ & 0,000 \\
\hline & ROA & 0,260 & 0,281 & 0,068 & 0,928 & 0,358 \\
\hline & TANG & 0,461 & 0,168 & 0,202 & 2,739 & 0,008 \\
\hline & Ukuran Perusahaan & 0,058 & 0,005 & 0,788 & 10,712 & 0,000 \\
\hline
\end{tabular}

Berdasarkan Tabel 3. dapat dibuat persamaan regresi linier berganda sebagai berikut: $\mathrm{Y}=-0,590+0,260 \mathrm{X}_{1}+0,461 \mathrm{X}_{2}+0,058 \mathrm{X}_{3}+0,135$. Konstanta ( $\alpha$ ) sebesar -0,590 memiliki arti apabila Profitabilitas, Struktur Aktiva, Ukuran Perusahaan memiliki nilai konstan pada angka nol maka nilai Struktur Modal Perusahaan akan menurun sebesar 0,590 satuan. Koefisien regresi variabel Profitabilitas sebesar 0,260 memiliki arti apabila Profitabilitas meningkat satu satuan maka Struktur Modal Perusahaan meningkat sebesar 0,260 satuan dengan asumsi variabel lainnya konstan. Koefisien regresi variabel Struktur Aktiva sebesar 0,461 memiliki arti apabila struktur aktiva meningkat satu satuan maka Struktur Modal Perusahaan meningkat sebesar 0,461 satuan dengan asumsi variabel lainnya konstan. Koefisien regresi variabel Ukuran Perusahaan sebesar 0,058 memiliki arti apabila Ukuran Perusahaan meningkat satu satuan maka Struktur Modal Perusahaan meningkat sebesar 0,058 satuan dengan asumsi variabel lainnya konstan.

Uji normalitas data dalam penelitian ini menggunakan Kolmogorov-Smirnov Test untuk masing-masing variabel. Apabila sig (2-tailed) lebih besar dari level of significant $(\alpha=0,05)$, maka dapat disimpulkan bahwa residual yang dianalisis berdistribusi normal, sedangkan apabila sig (2-tailed) lebih kecil dari level of significant $(\alpha=0,05)$, maka dapat disimpulkan bahwa residual yang dianalisis berdistribusi tidak normal. Hasil Uji normalitas dapat dilihat pada Tabel 4. 
Tabel 4.

Hasil Uji Normalitas

\begin{tabular}{lr}
\hline & \multicolumn{2}{c}{ Unstandardized } \\
& Residual \\
\hline $\mathrm{N}$ & 56 \\
Kolmogorov - Smirnov Z & 0,097 \\
Asymp. Sig. (2-tailed) & 0,200 \\
\hline Sumber: Data diolah, 2018 &
\end{tabular}

Berdasarkan Tabel 4. diketahui nilai signifikansi dengan menggunakan uji Kolmogorov - Smirnov sebesar 0,200 > 0,05 maka dapat disimpulkan bahwa data yang digunakan dalam penelitian ini terdistribusi secara normal.

Uji multikolinearitas bertujuan untuk menguji apakah pada model regresi ditemukan adanya korelasi yang cukup kuat antara variabel bebas. Jika terdapat korelasi yang cukup kuat akan menyebabkan problem multikolinieritas. Model regresi yang baik seharusnya tidak terjadi korelasi yang cukup kuat antara variabel independen. Identifikasi secara statistik untuk menunjukkan ada tidaknya gejala multikolinieritas dapat dilakukan dengan melihat nilai VIF (Variance Inflation Factor). Indikasi adanya multikolinieritas yaitu apabila VIF lebih dari 10 . Sebaliknya apabila nilai VIF kurang dari 10 maka tidak terjadi multikolinieritas. Hasil Uji multikolinieritas dapat dilihat pada Tabel 5.

Tabel 5.

Hasil Uji Multikolinieritas

\begin{tabular}{llcc}
\hline \multicolumn{2}{l}{ Model } & \multicolumn{2}{c}{ Collinearity Statistics } \\
\multicolumn{1}{l}{ ROA } & Tolerance & VIF \\
\hline \multicolumn{2}{r}{ TANG } & .966 & 1.035 \\
& Ukuran Perusahaan & .943 & 1.061 \\
\multicolumn{2}{l}{ Sumber: Data diolah, 2018 } & .950 & 1.052 \\
\cline { 2 - 3 }
\end{tabular}

Berdasarkan hasil uji pada Tabel 5. dapat diketahui bahwa setiap variabel pada model regresi berganda tersebut memiliki nilai tolerance lebih besar dari 0,1 dan nilai VIF lebih kecil dari 10, maka dapat disimpulkan bahwa data yang digunakan bebas multikolinieritas.

Tabel 6.

Hasil Uji Autokorelasi

\begin{tabular}{lrrrrr}
\hline Model & R & R Square & $\begin{array}{c}\text { Adjusted R } \\
\text { Square }\end{array}$ & $\begin{array}{l}\text { Std. Error of } \\
\text { the Estimate }\end{array}$ & $\begin{array}{c}\text { Durbin- } \\
\text { Watson }\end{array}$ \\
\hline 1 & $.856^{\mathrm{a}}$ & .732 & .717 & .22091 & 1.711 \\
\hline Sumber: Data diolah, 2018 & & & &
\end{tabular}

Dengan level of signifikan sebesar 0,05 dan $\mathrm{N}=56$ dan jumlah variabel bebas $\mathrm{k}=3$, maka diperoleh nilai $\mathrm{d}_{1}=1,4581$ dan $\mathrm{d}_{\mathrm{u}}=1,6830$ diperoleh nilai ( 4 $\mathrm{d}_{\mathrm{u}}$ ) sebesar $4-1,6830=2,317$. Oleh karena nilai Durbin Watson sebesar 1,711 berada diantara 1,6830 dan 2,317 sehingga dapat disimpulkan bahwa tidak terjadi autokorelasi. 
Selain menggunakan plot gambar scatter plot, penelitian ini juga menggunakan uji Glejser. Dalam uji Glejser ada tidaknya heteroskedastisitas dilakukan dengan melihat nilai signifikansi hasil regresi apabila lebih besar dari 0,05 maka tidak terjadi heteroskedastisitas. Hasil Uji heteroskedastisitas dapat dilihat pada Gambar 1.

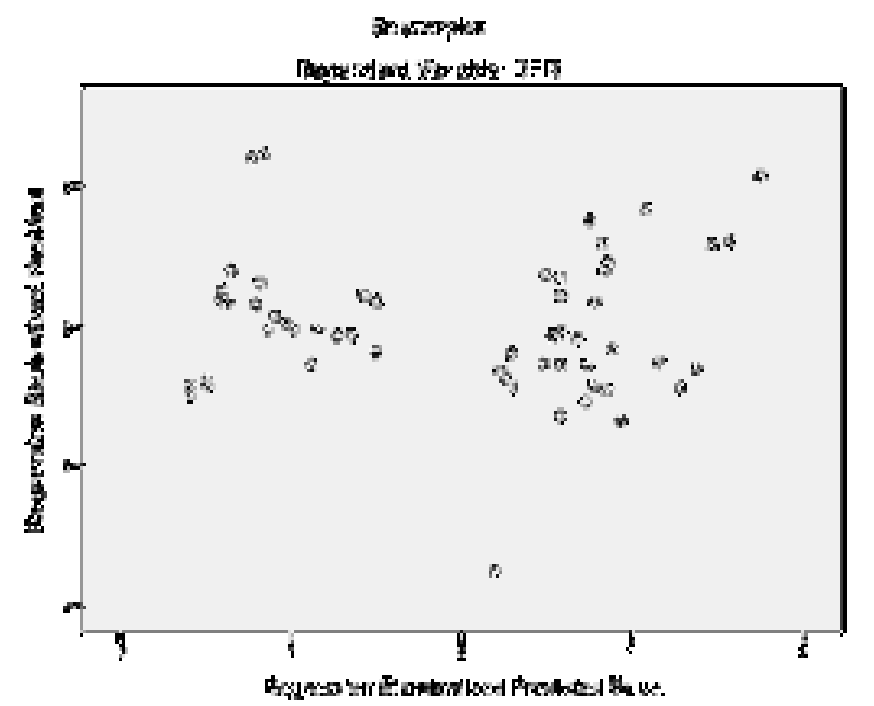

\section{Gambar 1. Hasil Uji Heteroskedastisitas Scatterplot}

Sumber: Data diolah, 2018

Berdasarkan Gambar 1. diatas dapat dilihat bahwa Titik-titik data menyebar di atas dan di bawah atau di sekitar angka 0, Titik-titik data tidak mengumpul hanya di atas atau di bawah saja, Penyebaran titik-titik data tidak membentuk pola bergelombang melebar kemudian menyempit dan melebar kembali dan Penyebaran titik-titik data tidak berpola, maka tidak terjadi heteroskedastisitas pada model regresi.

Tabel 7.

Hasil Uji Heteroskedastisitas Gletjer

\begin{tabular}{|c|c|c|c|c|c|c|}
\hline \multirow{2}{*}{\multicolumn{2}{|c|}{ Model }} & \multicolumn{2}{|c|}{$\begin{array}{l}\text { Unstandardized } \\
\text { Coefficients }\end{array}$} & \multirow{2}{*}{$\begin{array}{c}\text { Standardized } \\
\text { Coefficients } \\
\text { Beta }\end{array}$} & \multirow[t]{2}{*}{$\mathbf{t}$} & \multirow[t]{2}{*}{ Sig. } \\
\hline & & B & Std. Error & & & \\
\hline \multirow[t]{4}{*}{1} & (Constant) & .047 & .086 & & .547 & .587 \\
\hline & ROA & .189 & .178 & .146 & 1.065 & .292 \\
\hline & TANG & -.036 & .107 & -.047 & -.336 & .738 \\
\hline & Ukuran Perusahaan & .005 & .003 & .186 & 1.354 & .182 \\
\hline
\end{tabular}

Berdasarkan tabel di tersebut dapat dilihat semua nilai signifikansi hasil regresi apabila lebih besar dari 0,05 maka tidak terjadi heteroskedastisitas. 
Tabel 8.

Hasil Uji Parsial (Uji-t)

\begin{tabular}{llrrrrr}
\hline Model & \multicolumn{2}{c}{$\begin{array}{c}\text { Unstandardized } \\
\text { Coefficients }\end{array}$} & $\begin{array}{c}\text { Standardized } \\
\text { Coefficients } \\
\text { Beta }\end{array}$ & T & Sig. \\
& \multicolumn{1}{c}{ B } & Std. Error & \multicolumn{2}{c}{. } & \\
\hline 1 & (Constant) & -.590 & .135 & & -4.358 & .000 \\
& ROA & .260 & .281 & .068 & .928 & .358 \\
& TANG & .461 & .168 & .202 & 2.739 & .008 \\
& Ukuran Perusahaan & .058 & .005 & .788 & 10.712 & .000 \\
\hline
\end{tabular}

Sumber: Data diolah, 2018

Berdasarkan Tabel 8. dapat dilihat bahwa variabel Profitabilitas memliliki nilai $\beta_{1}$ sebesar 0,260 bernilai positif serta besar signifikansi 0,358 lebih besar dibandingkan dengan 0,05 maka $\mathrm{H}_{1}$ ditolak, dengan kata lain Profitabilitas tidak berpengaruh terhadap struktur modal perusahaan makanan dan minuman di Bursa Efek Indonesia.

Berdasarkan Tabel 8. dapat dilihat bahwa variabel Struktur Aktiva memiliki nilai $\beta_{2}$ sebesar 0,461 yang bernilai positif serta besar signifikansi 0,008 lebih kecil dibandingkan dengan 0,05 maka $\mathrm{H}_{2}$ diterima, dengan kata lain Struktur aktiva berpengaruh positif terhadap struktur modal perusahaan makanan dan minuman di Bursa Efek Indonesia, hal ini menunjukkan apabila terjadi peningkatan Struktur Aktiva maka akan terjadi peningkatan pula pada Struktur Modal Perusahaan.

Berdasarkan Tabel 8. dapat dilihat bahwa variabel Ukuran Perusahaan lmemiliki nilai $\beta_{3}$ sebesar 0,058 yang bernilai positif serta besar signifikansi 0,000

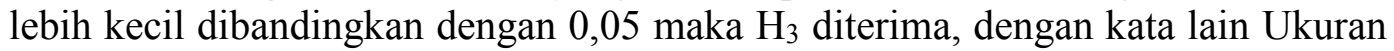
perusahaan berpengaruh positif terhadap struktur modal perusahaan makanan dan minuman di Bursa Efek Indonesia, hal ini menunjukkan apabila terjadi peningkatan ukuran perusahaan maka akan terjadi peningkatan pula pada Struktur Modal Perusahaan.

Uji $\mathrm{F}$ digunakan untuk mengetahui apakah permodelan yang dibangun memenuhi kriteria fit atau tidak. Memilih uji $\mathrm{F}$ karena hendak menentukan pengaruh berbagai variabel independen secara bersama-sama terhadap variabel dependen. Apabila nilai $F$ hitung lebih besar dari $F$ tabel maka variabel independen signifikan secara bersama-sama terhadap variabel dependen. Hasil uji simultan F dapat dilihat pada Tabel 9.

Tabel 9.

Hasil Uji Signifikansi Kelayakan Model F

\begin{tabular}{llrrrrr}
\hline Model & $\begin{array}{c}\text { Sum of } \\
\text { Squares }\end{array}$ & df & $\begin{array}{c}\text { Mean } \\
\text { Square }\end{array}$ & F & Sig. \\
\hline 1 & Regression & 6.948 & 3 & 2.316 & 47.457 & $.000^{\mathrm{b}}$ \\
& Residual & 2.538 & 52 & .049 & & \\
& Total & 9.485 & 55 & & & \\
\hline
\end{tabular}

Sumber: data diolah, 2018

Berdasarkan Tabel 9. dapat dilihat nilai signifikan $\mathrm{F}$ yakni 0,000 kurang dari $0,05(0,000<0,05)$ dengan nilai $\mathrm{F}$ hitung yakni 47,457 dan $\mathrm{F}$ tabel dengan derajat kebebasan $\mathrm{N}-\mathrm{k}=56-4=52$ dan $\mathrm{k}-1=4-1=3$ yakni 2,78. Karena nilai $\mathrm{F}$ 
hitung $>\mathrm{F}$ tabel $(47,457>2,78)$ Maka $\mathrm{H}_{0}$ ditolak dengan kata lain ada pengaruh profitabilitas, struktur aktiva, dan ukuran perusahaan terhadap struktur modal serta model layak untuk digunakan.

Setiap tambahan satu variabel independen, maka $\mathrm{R}^{2}$ pasti akan meningkat tanpa melihat apakah variabel tersebut berpengaruh secara signifikan terhadap variabel dependen. Oleh karena itu, banyak peneliti menganjurkan untuk menggunakan Adjusted $\mathrm{R}^{2}$ untuk mengevaluasi model regresi karena Adjusted $\mathrm{R}^{2}$ dapat naik atau turun apabila satu variabel independen ditambahkan ke dalam model. Hasil ujikoefisien determinasi dapat dilihat pada Tabel 10.

Tabel 10.

Hasil Uji Koefisien Determinasi

\begin{tabular}{lcrrr}
\hline \multicolumn{5}{c}{ Model Summary $^{\mathbf{b}}$} \\
\hline Model & $\mathrm{R}$ & R Square & Adjusted R Square & Std. Error of the Estimate \\
\hline 1 & $.856^{\mathrm{a}}$ & .732 & .717 & .22091 \\
\hline
\end{tabular}

Sumber: data diolah, 2018

Berdasarkan Tabel 10. dapat diamati nilai adjused $\mathrm{R}^{2}$ sebesar 0,717 berarti 71,7\% perubahan (naik turun) pada Struktur Modal Perusahaan yang dipengaruhi oleh Profitabilitas, Ukuran Perusahaan, Struktur Aktiva, sementara sisanya sejumlah 28,3\% dipengaruhi oleh faktor - faktor lain diluar penelitian ini.

Penelitian ini bertujuan untuk mengetahui pengaruh profitabilitas, struktur aktiva, dan ukuran perusahaan baik secara parsial maupun simultan terhadap struktur modal perusahaan makanan dan minuman di Bursa Efek Indonesia periode $2014-2017$.

Hasil analisis statistik untuk variabel profitabilitas diketahui bahwa koefisien regresi profitabilitas bernilai positif sebesar 0,260. Hasil statistik uji-t untuk variabel profitabilitas diperoleh nilai signifikan sebesar 0,358, sehingga lebih besar dari toleransi kesalahan sebesar 0,05. Dapat disimpulkan bahwa profitabilitas tidak berpengaruh terhadap struktur modal pada sektor makanan dan minuman di Bursa Efek Indonesia periode 2014 - 2017, sehingga hipotesis pertama yang diajukan ditolak.

Profitabilitas adalah kemampuan perusahaan untuk menghasilkan laba dari aktiva yang dimiliki. Perusahaan yang memiliki tingkat pengembalian yang tinggi atas aktiva yang dikelolanya menggambarkan kemampuan perusahaan menghasilkan laba yang tinggi. Stabilnya tingkat profitabilitas yang dimiliki perusahaan merupakan salah satu hal penting yang harus diperhatikan manajer didalam pemilihan struktur modal. Semakin stabil profitabilitas berarti semakin kecil pinjaman yang dilakukan perusahaan. Namun hasil penelitian ini tidak sesuai dengan pernyataan diatas dan tidak mendukung hipotesis penelitian.

Hasil menunjukkan bahwa profitabilitas tidak berpengaruh terhadap struktur modal pada sektor makanan dan minuman di Bursa Efek Indonesia periode 2014 2017, karena perusahaan telah menetapkan struktur modalnya berdasarkan besarnya manfaat (return) dan pengorbanan (biaya modal) yang dihasilkan dari penggunaan hutang untuk mendukung operasional perusahaan (Mustika, 2014). Berdasarkan trade off theory dalam Mustaqim (2012) perusahaan yang memiliki tingkat profitabilitas yang tinggi lebih memilih menggunakan hutang dalam 
pemenuhan pendanaan perusahaannya karena adanya manfaat dari penggunaan hutang yang disebabkan oleh biaya bunga nantinya akan dapat dikurangkan dengan pajak perusahaan. Hasil penelitian ini didukung oleh penelitian Seftianne dan Handayani (2011), Ginanjar dkk. (2012), dan Putri (2012), dalam penelitiannya menemukan bahwa profitabilitas tidak berpengaruh terhadap struktur modal.

Hasil analisis statistik untuk variabel struktur aktiva diketahui bahwa koefisien regresi struktur aktiva bernilai positif sebesar 0,461 . Hasil statistik uji-t untuk variabel struktur aktiva diperoleh nilai signifikan sebesar 0,008, sehingga lebih kecil dari toleransi kesalahan sebesar 0,05. Dapat disimpulkan bahwa struktur aktiva berpengaruh positif secara signifikan terhadap struktur modal pada sektor makanan dan minuman di Bursa Efek Indonesia periode 2014 - 2017, sehingga hipotesis kedua yang diajukan diterima.

Menurut Athifah (2014) struktur aktiva mempunyai arah pengaruh positif terhadap struktur modal yang berarti semakin tinggi struktur aktiva yang dimiliki perusahaan, dalam hal ini banyaknya aktiva tetap berwujud yang dimiliki maka struktur modal perusahaan semakin meningkat dan sebaliknya sehingga akan mempermudah perusahaan untuk mendapatkan dana yaitu berupa hutang dari pihak eksternal karena aktiva tetap dapat dijadikan jaminan perusahaan untuk membayar hutang serta mendapatkan pinjaman untuk mengatasi kesulitan keuangan perusahaan. Hal ini berarti dengan semakin tingginya nilai struktur aktiva (aktiva tetap), perusahaan dapat menggunakan terlebih dahulu sumber dana eksternal, yaitu hutang jangka panjang sebagai alternatif pertama dalam membiayai aktivitas operasional dan investasinya dibandingkan modal sendiri. Tetapi terlalu sering menggunakan hutang juga akan menimbulkan beban dan resiko yang tinggi.

Pengaruh yang signifikan menunjukan bahwa perusahaan banyak memanfaatkan aktiva tetapnya sebagai jaminan dalam memperoleh hutang. Dengan demikian maka perusahaan dengan aktiva tetap yang tinggi memiliki kesempatan besar dalam mendapatkan hutang jangka panjang. Akan tetapi perusahaan harus tetap berhati-hati dalam menggunakan kebijakan tersebut dengan memperhatikan besar bunga yang harus dibayarkan waktu jatuh tempo agar tidak sampai menyebabkan kerugian yang tidak diharapkan perusahaan.

Sesuai teori struktur modal yaitu trade off theory yang intinya menyatakan bahwa perusahaan harus menyeimbangkan antara manfaat menggunakan hutang dan biaya yang ditimbulkan dari penggunaan hutang untuk mencapai struktur modal optimal. Penelitian ini didukung oleh Kartika (2009), Putri (2012), Devi dan Mulyo (2013) serta Ferawati (2014) yang menyatakan bahwa struktur aktiva berpengaruh positif dan signifikan terhadap struktur modal

Hasil analisis statistik untuk variabel ukuran perusahaan diketahui bahwa koefisien regresi ukuran perusahaan bernilai positif sebesar 0,058. Hasil statistik uji-t untuk variabel ukuran perusahaan diperoleh nilai signifikan sebesar 0,000, sehingga lebih kecil dari toleransi kesalahan sebesar 0,05. Dapat disimpulkan bahwa ukuran perusdahaan berpengaruh positif secara signifikan terhadap struktur modal pada sektor makanan dan minuman di Bursa Efek Indonesia periode 2014 2017, sehingga hipotesis ketiga yang diajukan diterima. 
Hasil tersebut menemukan bahwa semakin besar ukuran perusahaan maka struktur modal akan semakin tinggi. Begitupun sebaliknya, semakin kecil ukuran perusahaan maka semakin kecil struktur modal. Perusahaan yang berskala besar akan lebih mudah dalam mencari investor yang hendak menanamkan modalnya dalam perusahaan dan juga dalam rangka perolehan kredit dibandingkan dengan perusahaan kecil. perusahaan besar memiliki kemudahan akses sehingga fleksibilitas perusahaan besar juga lebih besar. Pihak kreditur atau pemberi utang tentunya lebih menyukai untuk memberikan kredit kepada perusahaan besar sehingga perusahaan besar mempunyai kesempatan yang lebih luas.

Hasil penelitian ini sejalan dengan Indrajaya dkk. (2011), Putri (2012), Salehi dan Nazanin (2012), dan Cekrezi (2013) yang menyatakan ukuran perusahaan berpengaruh positif signifikan terhadap struktur modal.

Hasil penelitian ini memiliki implikasi teoritis dan praktis. Secara teoritis hasil penelitian ini menunjukkan bahwa profitabilitas, struktur aktiva, dan ukuran perusahaan mampu memprediksi kondisi struktur modal pada perusahaan makanan dan minuman di BEI periode 2014-2017. Penelitian ini menemukan bahwa profitabilitas tidak berpengaruh signifikan dalam memprediksi struktur modal. Hasil lainnya yaitu struktur aktiva dan ukuran perusahaan yang hasil penelitiannya berpengaruh positif secara signifikan dalam memprediksi struktur modal.

Implikasi praktis dalam penelitian ini adalah penelitian ini diharapkan dapat dijadikan sebagai acuan dan bahan pertimbangan bagi para investor untuk menganalisis dan memilih untuk berinvestasi di perusahaan yang tepat, sehingga investor dapat meminimalkan risiko dan mengoptimalkan keuntungan. Penelitian ini diharapkan agar dapat digunakan sebagai bahan pertimbangan dalam menentukan besarnya sumber dana yang dibutuhkan perusahaan, selain itu bagi pihak manajemen perusahaan diharapkan dengan adanya penelitian ini maka dapat meningkatkan kinerja manajemen yang tercermin dari hasil laporan keuangan perusahaan.

Berdasarkan dengan hasil dari uji statistik, profitabilitas tidak berpengaruh terhadap struktur modal. Pada saat perusahaan memiliki dana internal yang didapatkan dari hasil pemanfaatan aktivanya, perusahaan cenderung membagikan dananya kepada pemegang saham atau stakeholder. Sehingga perusahaan akan menggunakan dana eksternal untuk pendanaan investasinya. Kondisi ini menyebabkan tinggi atau rendahnya profitabilitas atau keuntungan perusahaan tidak akan memengaruhi keputusan pendanaan perusahaan. Tinggi atau rendah profitabilitas juga tidak akan memengaruhi perimbangan permodalan perusahaan. Perusahaan yang menggunakan dana internalnya untuk menyejahterakan stakeholder akan mengurangi pendapatan bersih perusahaan, hal ini akan berfungsi untuk mengurangi beban pajak perusahaan.

Ukuran perusahaan yang semakin besar menyebabkan perusahaan akan cenderung menggunakan aktivanya sebagai jaminan untuk mendapatkan dana eksternal. Struktur aktiva perusahaan meningkatkan dana eksternalnya yang didapatkan dari menggunakan aktivanya sebagai jaminan. Sebagian besar perusahaan yang memiliki ukuran perusahaan besar serta struktur aktiva yang 
tinggi akan lebih cenderung menggunakan aktiva yang dimiliki perusahaan sebagai jaminan perusahaan dalam mendapatkan pendanaan eksternal.

Hasil analisis koefisien determinasi dapat diamati nilai adjused $\mathrm{R}^{2}$ sebesar 0,717 berarti 71,7\% perubahan (naik turun) pada Struktur Modal Perusahaan yang dipengaruhi oleh Profitabilitas, Ukuran Perusahaan, Struktur Aktiva, sementara sisanya sejumlah $28,3 \%$ dipengaruhi oleh faktor - faktor lain diluar penelitian ini. variabel-variabel yang diuji dalam penelitian ini memiliki pengaruh dominan dalam memengaruhi struktur modal perusahaan. seharusnya faktor-faktor ini menjadi faktor dijadikan ukuran untuk perusahaan dalam mengatur perimbangan permodalan perusahaan.

\section{SIMPULAN}

Profitabilitas tidak berpengaruh terhadap struktur modal perusahaan makanan dan minuman di Bursa Efek Indonesia. Hal ini berarti apabila Profitabilitas semakin meningkat ataupun menurun maka tidak akan memengaruhi peningkatan dan penurunan dari struktur modal perusahaan makanan dan minuman di Bursa Efek Indonesia.

Struktur aktiva berpengaruh positif terhadap struktur modal perusahaan makanan dan minuman di Bursa Efek Indonesia. Hal ini berarti apabila Struktur Aktiva semakin meningkat maka Struktur Modal Perusahaan semakin meningkat pula.

Ukuran Perusahaan berpengaruh positif terhadap struktur modal perusahaan makanan dan minuman di Bursa Efek Indonesia. Hal ini berarti Hal ini berarti apabila ukuran perusahaan semakin meningkat maka Struktur Modal Perusahaan semakin meningkat pula.

Manajer perusahaan diharapkan mampu mempertimbangkan keputusan pendanaan yang akan diambil, baik menggunakan modal sendiri maupun hutang. Pendanaan tersebut diharapkan mampu memenuhi kebutuhan perusahaan serta dapat menciptakan Struktur Modal yang optimum.

Bagi peneliti yang akan datang, sebaiknya menambahkan variabel lain yang diduga dapat mempengaruhi struktur modal, baik yang berasal dari faktor internal maupun eksternal perusahaan.

\section{REFERENSI}

Adrianto, \& Wibowo, B. (2007). Pengujian Teori Pecking Order pada Perusahaan Non Keuangan LQ45 Periode 2001-2005. Manajemen Usahawan Indonesia, $36(12), 43-53$.

Andika, A. P. (2016). Pengaruh Struktur Aktiva, Ukuran Perusahaan, Profitabilitas dan Risiko Bisnis Terhadap Struktur Modal. Jurnal Ilmu Dan Riset Akuntansi, 5(9), 1-19.

Ariyanto, T. (2002). Pengaruh Struktur Kepemilikan terhadap Struktur Modal Perusahaan. Jurnal Manajemen Indonesia, 1 (1), 64-67

Asmawi, N. S., \& Faridah, S. (2013). The determinant of capital structure of 
SMEs in Malaysia: evidence from enterprise 50 (E50) SMEs. Asian Social Science, 9(6), 64-73.

Athifah, H. (2014). Pengaruh Pertumbuhan Penjualan, Profitabilitas, Struktur Aktiva Dan Ukuran Perusahaan Terhadap Struktur Modal (Studi Pada Perusahaan Property dan Real Estate yang Terdaftar di Bursa Efek Indonesia). ). Jurnal Manajemen Fakultas Ekonomi Dan Bisnis Universitas Brawijaya, 1(10), 7-9.

Baharuddin. (2011). Determinants of Capital Structure for Listed Construction Companies in Malaysia. Journal of Applied Finance \& Banking, 1 (2), 115132.

Brigham, \& Houston. (2011). Dasar-dasar manajemen keuangan, Buku 2 (Ed. 11). Jakarta: Salemba Empat.

Brigham dan Houston. (2014). Dasar-Dasar Manajemen Keuangan (Ed. 11). Jakarta: Salemba Empat.

Cekrezi, A. (2013). The Determinants of Capital Structure: A Case of Small NonTraded Firms in Albania.Global Virtual Conference. Global Virtual Conference, 3(3), 5-18.

Chowdhury, A., \& Chowdhury, S. P. (2012). Impact of capital structure on firm's value: Evidence from Bangladesh. Business and Economic Horizons, 3(3), 5-18.

Darmayanti, Ni Putu Ayu., dan Untari, Fenita Widya. (2012). Pengaruh Struktur Aktiva, Profitabilitas, dan Pertumbuhan Penjualan Terhadap Keputusan Pendanaan Pada Perusahaan Property dan Real Estate di Bursa Efek Indonesia Periode 2005-2010. Jurnal Matrik, 6 (1), 1-20.

Devi, \& Mulyo. (2013). Pengaruh Profitabilitas, Pertumbuhan Aset, Ukuran Perusahaan, Struktur Aktiva dan Likuiditas terhadap Struktur Modal Pada Perusahaan Manufaktur di Bursa Efek Indonesia Tahun 2008-2010. Universitas Diponegoro. Journal of Manajemen, 2(3), 1-11.

Fahmi, I. (2013). Pengantar Manajemen Keuangan. Bandung: Alfabeta.

Firnanti, F. (2011). Faktor-Faktor yang Mempengaruhi Struktur Modal Perusahaan Manufaktur di Bursa Efek Indonesia. Jurnal Bisnis Dan Akuntansi, 13(2), 119-128.

Frank, M., \& Goyal, V. (2009). Capital Structure Decisions: Which

Gamaliel, J., \& Sudjarni, L. K. (2015). Pengaruh Profitabilitas, Ukuran 
Perusahaan dan Struktur Aktiva Terhadap Struktur Modal pada Perusahaan Transportasi di Bursa Efek Indonesia. E-Jurnal Manajemen Universitas Udayana, 4(1), 59-74.

Gaud, P., Jani, E., Hoesli, M., \& Bender, A. (2005). The capital structure of Swiss companies: an empirical analysis using dynamic panel data. European Financial Management, 11 (1), 51-69.

Ghozali, Imam. (2011). Aplikasi Analisis Multivariate dengan Program IBM SPSS 19. Semarang: Badan Penerbit UNDIP.

Ginanjar, I. K., Suhadak, \& Zainul, A. (2012). Analisis Pengaruh Profitabilitas (Profitability) dan Tingkat Pertumbuhan (Growth) Terhadap Struktur Modal Dan Nilai Perusahaan (Studi Pada Perusahaan Real Estate and Property yang Terdaftar di Bursa Efek Indonesia (BEI) Periode 2007-2011). Jurnal Ilmu Administrasi, 7(2), 11-13.

Hanafi, Mamduh M. (2016). Manajemen Keuangan. Edisi kedua, Cetakan pertama. Yogyakarta: BPFE

Handoo, A., \& Sharma, K. (2014). A Study on Determinants of Capital Structure in India. IIMB Management Review, 26 (3), 170-182.

Harahap, Sofyan Syafri. (2013). Analisis Kritis Atas Laporan Keuangan. Cetakan Kesebelas. Jakarta: Rajawali Pers.

Huang, G. and Song, F.M. (2006). The determinants of capital structure: evidence from China. China Economic Review, 17 (2), 14-36.

Husnan, Suad. (2012). Manajemen Keuangan Teori dan Penerapan (Keputusan Jangka Panjang). Yogyakarta : BPFE

Indrajaya, G., Herlin, \& Setiadi, R. (2011). Pengaruh Struktur Aktiva, Ukuran Perusahaan, Tingkat Pertumbuhan, Profitabilitas dan Risiko Bisnis Terhadap Struktur Modal: Studi Empiris Pada Perusahaan Sektor Pertambanangan yang Listing Di Bursa Efek Indonesia Periode 2004-2007. Jurnal Ilmiah Akuntansi, 2(6), 14-36.

Kartika, A. (2009). Faktor-Faktor Yang Mempengaruhi Struktur Modal Pada Perusahaan Manufaktur yang Go Public di BEI. Dinamika Keuangan Dan Perbankan, 1(2), 105-122.

Kasmir. (2014). Analisis Laporan Keuangan. Jakarta: Rajawali Pers.

Kesuma, A. (2009). Analisis Faktor yang Mempengaruhi Struktur Modal Serta Pengaruhnya Terhadap Harga Saham Perusahaan Real Estate yang Go 
Public di Bursa Efek Indonesia. Jurnal Manajemen Dan Kewirausahaan, 11(1), 38-45.

Lisa, Oyong. (2016). Determinants Distribution of Financing and the Implications to Profitability: Empirical Study on Cooperative Sharia Baitul Maal wa Tamwil (BMT) in Indonesia. Asian Journal of Accounting Research, 1 (2), 44-51.

Margaretha, F., \& Ramadhan, A. R. (2010). Faktor-Faktor yang Mempengaruhi Struktur Modal Pada Industri Manufaktur di Bursa Efek Indonesia. Jurnal Bisnis Dan Akuntansi, 12(2), 119-130.

Michael, A. C., \& Stevie, S. (2012). The determinants of corporate capital structure: evidence from japanese manufacturing companies. Journal of International Business Research, 11(3), 122-133.

Naibaho, T., \& Azizah, D. F. (2015). Pengaruh profitabilitas, pertumbuhan penjualan, struktur aktiva dan ukuran perusahaan terhadap struktur modal (studi kasus pada perusahaan property and real estate yang terdaftar di BEI tahun 2011-2013). Jurnal Administrasi Bisnis (JAB), 28(1), 131-142.

Owolabi, S. A., dan Inyang, K. E. (2012). Determinants of Capital Structure in Nigeria Firms: A Theoritical Reviews. eCanadian Journal of Accounting and Finance, 1 (1), 7-15.

Putri, M. E. D. (2012). Pengaruh Profitabilitas, Struktur Aktiva, dan Ukuran Perusahaan terhadap Struktur Modal pada Perusahaan Manufaktur Sektor Industri Makanan dan Minuman yang Terdaftar di Bursa Efek Indonesia. Jurnal Manajemen, 1(1), 1-10.

Rahyuda, Ketut. (2016). Metodologi Penelitian Bisnis. Denpasar: Udayana University Press

Ramlall. (2009). Determinant of Capital structure Among Non-Quoted Mauritian Firms Under Specificity of Laverage: Looking for a Modified Pecking Order Theory. International Research Journal of Finance and Economics, $31(1), 83-92$.

Rofiqoh, N., \& Kurnia. (2014). Pengaruh Struktur Aktiva, Likuiditas dan Profitabilitas terhadap Struktur Modal Perusahaan. Jurnal Ilmu \& Riset Akuntansi, 3(2), 1-15.

Ruslim, Herman. (2009). Pengujian Struktur Modal (Teori Pecking Order): Analisis Empiris Terhadap Saham di LQ 45. Jurnal Bisnis dan Akuntansi, 11 (3), 209-221. 
Salehi, M., \& Manesh, N. B. (2012). A Study of the Roles of Firm and Country on Specific Determinates in Capital Structure: Iranian Evidence. International Management Review, 8(2), 51-85.

Sari, N. P. A. P. (2014). Faktor-Faktor yang Mempengaruhi Struktur Modal Pada Perusahaan Non Keuangan yang Terdaftar di Bursa Efek Indonesia Tahun 2008-2012. E-Jurnal Akuntansi Universitas Udayana, 7(1), 33-47.

Seftianne dan Handayani. (2011). Faktor - Faktor yang Mempengaruhi Struktur Modal pada Perusahaan Publik Sektor Manufaktur. Jurnal Bisnis Dan Akuntansi, 13(1), 39-56.

Sheikh, N. A., dan Zongjun, W. (2011). Determinant of Capital Structure An Empirical Study of Firms in Manufacturing Industry of Pakistan. Journal Managerial Finance, 37 (2), 117-133.

Songul, K. A. (2015). The determinants of capital structure:evidence from the Turkish manufacturing sector. International Journal of Economics and Financial Issues, 5 (1), 158-171.

Turki, S. F. A. (2014). Capital structure determinants of publicly listed companies in Saudi Arabia. The International Journal of Business and Finance Research, 8(2), 53-67.

Voulgaris, F., Asteriou, D. and Agiomirgianakis, G. (2004). Size and determinants of capital structure in the Greek manufacturing sector. International Review of Applied Economics, 18 (2), 247-262.

Wiagustini, N. L. P. (2014). Manajemen Keuangan. Denpasar: Udayana University Press.

Widianti, E. ., \& Andayani. (2015). Pengaruh profitabilitas, ukuran perusahaan,dan struktur aktiva terhadap struktur modal. Jurnal Ilmu \& Riset Akuntansi, 4(10), 1-15.

Wijaya, I. P. A. S., \& Utama, I. M. K. (2014). Pengaruh Profitabilitas, Struktur Aset, dan Pertumbuhan Penjualan terhadap Struktur Modal serta Harga Saham. Jurnal Akuntansi Universitas Udayana, 6(3), 514-530.

Yat-Hung Chiang, Eddie W.L. Cheng, Patrick T.I. Lam. (2010). Epistemology of capital structure decisions by building contractors in Hong Kong. Construction Innovation, 10 (3), $329-345$

Zhang, Y. (2010). The Product Category Effects on Capital Structure: Evidence from the SMEs of British Manufacturing Industry. International Journal of Bussiness and Management,5 (8), 86-112. 
I Kadek Rico Andika. Pengaruh Profitabilas, Struktur.....

Zuliyani, S., \& Asyik, N. . (2014). Pengaruh profitabilitas, pertumbuhan penjualan, struktur aset, dan tingkat pertumbuhan terhadap struktur modal. Jurnal Ilmu \& Riset Akuntansi, 3(7), 1-16. 